\title{
The Identification of Kutai Kartanegara Traditional Architecture Identity Based on Comparative Analysis
}

\author{
March Endika ${ }^{1}$ and Arif Budi Sholihah ${ }^{2}$ \\ ${ }^{1}$ Department of Architecture, Faculty of Civil Engineering and Planning, Uni- \\ versitas Islam Indonesia, Yogyakarta \\ ${ }^{2}$ Department of Architecture , Faculty of Civil Engineering and Planning, Uni- \\ versitas Islam Indonesia, Yogyakarta
}

\author{
Article History \\ Received : 07 April 2017 \\ Accepted : 24 May 2017 \\ Published: 30 Oktober 2017
}

\begin{abstract}
Kutai Kartanegara in the past was part of The Kingdom of Kutai, the oldest kingdom in Indonesia from the 4th to to 13th century. However, the data about this kingdom is very limited including the information about the architecture at that era. The interest to identify the character of Kutai Kartanegara such as the architecture has grown from the government and the society as the media to express the local identity. Thus, this research aims to identify the traditional architectural features of Kutai Kartanegara based on comparative analysis with the house of Lamin Dayak Kenyah and Architecture of Melayu Perak Malaysia. The method used in this research is comparison between traditional architecture of Dayak ethnicity and Malay traditional architecture through literature review. The result of library studies is then compared with the empirical data about traditional architecture of Kutai Kartanegara from field observation and measured drawing to one of the selected cases of traditional house of Kutai. From the findings of this research, it can be concluded that besides there is similarity with the two comparing architectures, the traditional architecture of Kutai has the specialty from the morphological aspect of layout and orientation. In addition, it also functions as single family dwelling with simpler geometrical ornamentation.
\end{abstract}

Keyword: Traditional architecture, identity, Kutai Kartanegara.

\section{Introduction}

Kutai Kartanegara in the past was part of The from the 4 th to 13 th century. The information about this kingdom was obtained from seven ancient inscriptions of Yupa, stone column of commemoration used by all the Hindu Brahman priests. From the Yupa, it can be known that Kutai Kingdom is the Hindu Kingdom with a king named Mulawarman. However, further details information about this kingdom is very limited including information about the architecture in that era.

Correspondence: Arif Budi Sholihah.

Department of Architecture , Faculty of Civil Engineering and Planning, Universitas Islam Indonesia, Yogyakarta. E-mail: sholihah@uii.ac.id
At the moment, the government of Kutai Kartanegara is still not sure with the identity of traditional architecture of Kutai. Up to this present, the government used architecture of Dayak ethnic or Malay architecture, which were admitted as traditional architecture of Kutai. In fact, based on preliminary study, Kutai traditional architecture is not included in both kinds of architecture. Kutai as an ethnicity who stays in the area is believed to have its own architectural identity. Thus, the research about the local identity of Kutai traditional architecture is highly need to contribute differentiation of traditional architecture of Kutai compared to other ethnicities. This research is also expected to identify the richness of traditional architecture from Nusantara that were so various and diverse. This research therefore aims to identify the characteristics of traditional architecture from Kutai Kartanegara based on com- 
parative analysis with the house of Lamin from Dayak Kenyah and Malay architecture from Perak, Malaysia.

\section{Nusantara Traditional Architecture, Identity, and Architecture of Kutai}

Ideality concept of a place started to develop in the 1970s. Relph (1976) stated that identity of a place is strongly related with the sense of belonging and bonds to a certain place. Proshansky (1983) emphasized that identity of a place is a collection of memory and feeling of connection with a physical setting of a place including with architectural works. The works of architecture are often used as media to express identity of certain group or particular ethnicity. Traditional architecture can be specifically used to exactly represent the cultural values of certain group of society (Nas, 2004).

Indonesia is very rich with architectural diversity both vernacular and traditional. Morphologically, the richness of architectural physical setting is unique and dissimilar between one place and the other place. Selecting architecture as an object of studies in Indonesia is not a difficult decision. Traditional houses in Nusantara are very important objects to be studied not only because of the great architecture but also because of the transformation of traditional houses in the modern era in this present (Schefold, et al., 2004).

Further, Schefold, et al. (2004) highlighted that traditional architectures and settlements of hundreds ethnic groups in Indonesia are very diverse and they have special history. The comparison of architecture from various groups of ethnicities will provide deeper understanding about shared tradition and about how vernacular architecture developed to be evolving tradition from time to time. However, the cultural values and the uniqueness of history still have the position to give identity for every traditional architecture of an ethnic group that is distinctive with other group (mutual contrasting).
Vernacular architecture is the product of local community or 'architecture without architects' that is based on the material, resources, culture, and local people's need (Rudofsky, 1964, Rapoport, 1981, Oliver, 1997). Vernacular architecture can keep spontaneously developing in the society and in the end it will be inherited from generation to generation to form tradition. The architecture that has become the tradition is known as traditional architecture (Noble, 2007). However, in practice, the term vernacular and traditional architecture is often used interchangeably to refer to the same object. Research about traditional architecture needs to compare architectures from different ethnics (interethnic comparison) in similar local setting (climate and nature) to help researcher to gain deeper understanding towards the shared tradition and diverging development from the architectural and structural aspect (Schefold, et al., 2004). Research about vernacular and traditional architecture of Kutai has been done by some researchers. Some researches discussed about adaptation of vernacular house in Kutai towards floodprone environment (Hidayati \& Octavia, 2013) and structural and construction system of Kutai vernacular house (Hidayati \& Octavia, 2014). Both researches put an emphasis on the performance of Kutai vernacular house from the aspect of structure and adaptation towards climate. Nonetheless, no research has tried to identify vernacular and traditional architecture characteristics of Kutai compared with traditional architecture in Nusantara and other similar type of architecture in the surrounding area.

Figure 1. Map of Kutai Kartanegara area in Indonesian context (Source: Google Map, 2017)

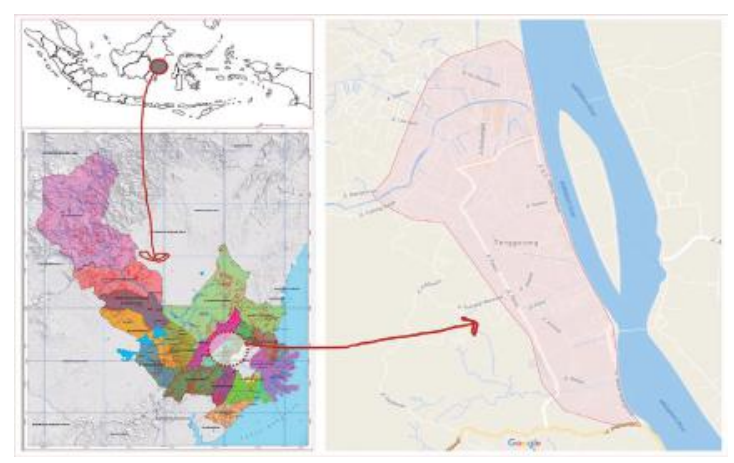




\section{Research Methodology}

The method used in this research is comparative method between traditional architecture of Dayak ethnicity and Malay with the data from library studies. The result of literature review was the compared with the traditional architecture of Kutai Kartanegara with empirical data from field observation and measured drawing arrangement. Traditional house of Kutai was selected because it is one of few houses built in Tenggarong in 1894. Architectural analysis was then conducted with some parameters such as structures and construction (foundation, pond, walls, and roof), and details (ornaments) in both comparing buildings (traditional architecture of Dayak Kenyah and Malay) and Kutai.

\section{Results and Discussion Architecture of Malay Perak Malay- sia}

From the general aspect of culture, three cases are located in the same area i.e. Nusantara especially in Borneo Island (Kutai and Dayak ethnicity) and in eastern part of the Malay Peninsula that is facing to Borneo Island (Malay ethnic). From the language aspect

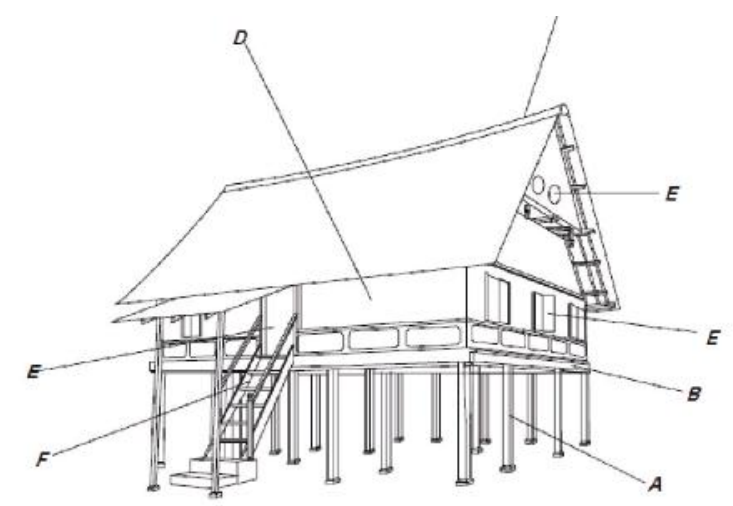

[a]
(Ethnologue), the language of Kutai ethnicity can be categorized as Malay language with slight difference on the pronunciation of vowels 'a' to be 'e'. Meanwhile, Dayak ethnicities use the native language of Borneo that is spread all across the Island of Borneo, Malaysia, and Sulu Island of The Philippines. From the aspect of religiosity or belief, Kutai people are mostly Muslim as the Malay ethnicity. However, Dayak ethnicity is usually categorized as non-Muslim and non-Malay and Dayak is the native people who inhabit the Island of Borneo (King, 1993).

The architecture of Melayu Perak is often called as Kutai House, which means old house. The type of the house is stage house with the height around two meters above the land level. The shape of the house is square with symmetrical construction with stairs as the main access both in the front and in the back parts of the house. The shape of the roof is like a gabble with steep declivity around 50 degree. The house consists of two types, i.e. house with 16 columns and house with 12 columns (see the picture below) (Arrifin \& Talib, 2004).

Figure 2. Components in the Architecture of Melayu Perak (Source: Talib \& Ariffin, 2004)

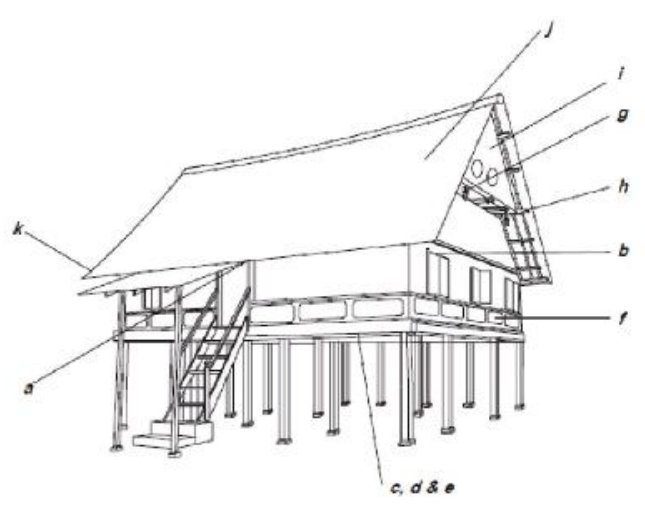

[b] 
Figure 3 Layout and Architectural Setting of Melayu Perak House (Source: Talib \& Ariffin, 2004).

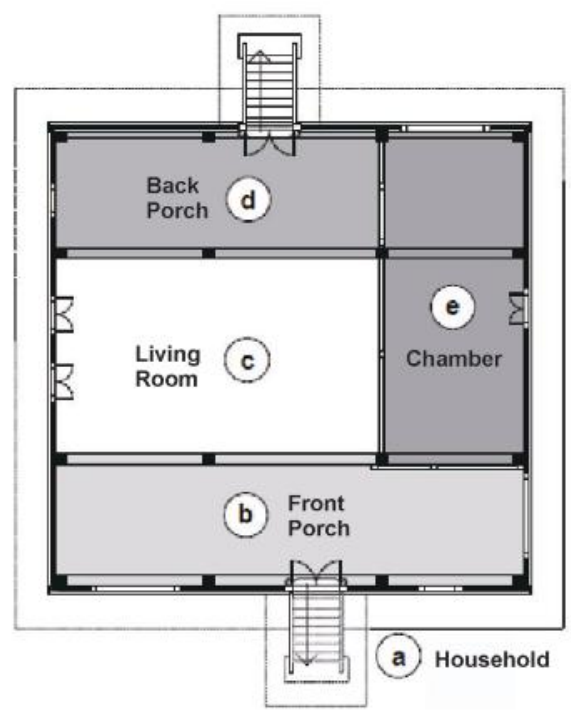

[a]

The layout of Melayu Perak House is influenced by gender aspect in the tradition of Islam (muhrim and non muhrim). The access of the front part of the house until the veranda is specifically provided for the male, while the access for the back part and the back porch is dedicated for the female (Norhasandi,et al., 2012).

Figure 4. The Architecture of Melayu Perak House (Source: Talib \& Ariffin, 2004).

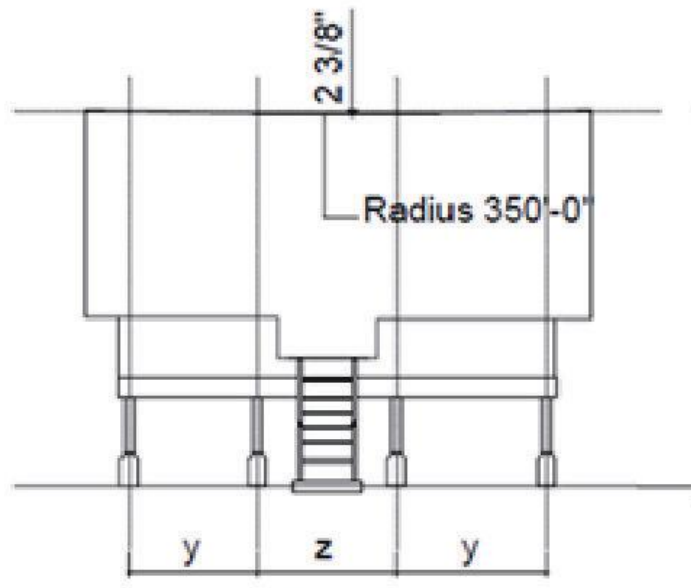

Front Elevation

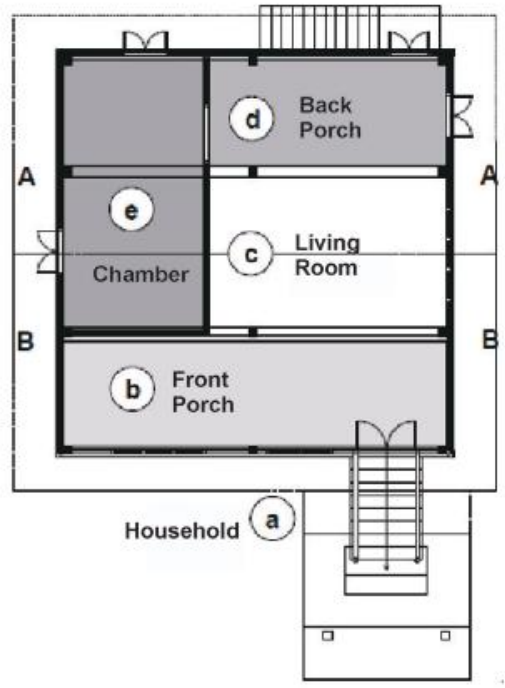

[b]
From the ornamentation aspect, the carving in Melayu Perak house is influenced by the culture from India and Islam (Norhasandi, dkk, 2012). The carving is using the shape of plants with organic style and a more formal geometry. The carving is located in the opening element such as above the door, window, and the column as the main structure.

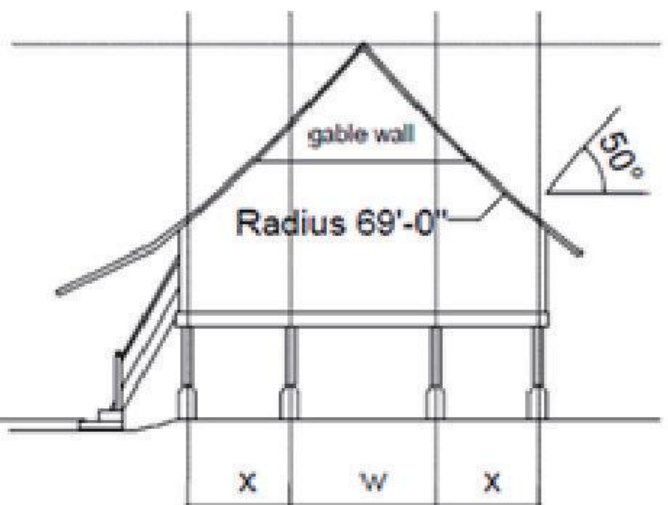

Side Elevation 
Figure 5. Ornament on the Architecture of Melayu Perak House (Source: Norhasandi, et al, 2012)
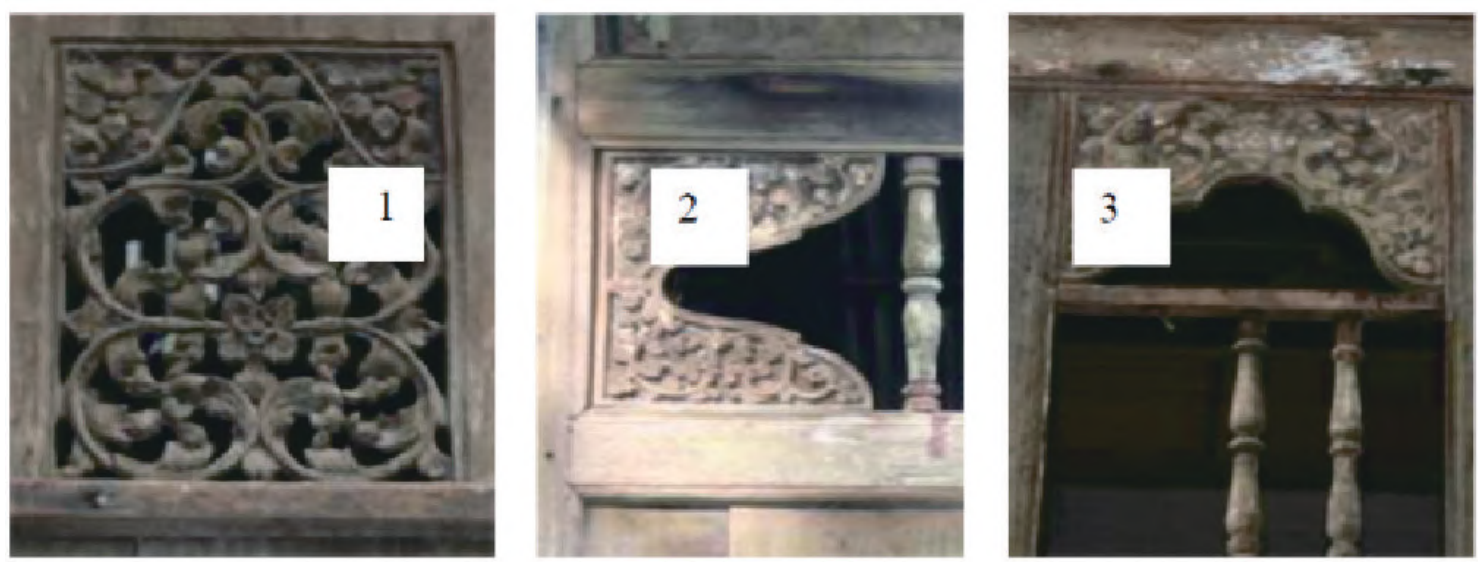

Architecture of Lamin Dayak Kenyah Borneo

sists of 4 main rooms i.e. kitchen, bedroom, middle room, and guest room. Since Lamin house is inhabited by more than one family,

Lamin House is the traditional house of Dathen every family has their own kitchen and the yak Kenyah people inhabited by more than 30 families at the same time with the length up to 250 meters (Kristian, 2004; Tjahjono \& Miksic, 2013). The type of the house is stage house with a very strong and long lasting ulin wood column with the diameter of 0.5-1 meter, length of 6 meters, and heights of 1-2 meter (Latenrilawa, 2014). The layout of Lamin House conguest room can play double function as common room and bedroom for children who are not married yet (Yuuwono, 2015).

Figure 6. Layout and Architecture of Lamin Dayak Kenyah House (Source: Ramadhan, 2016)

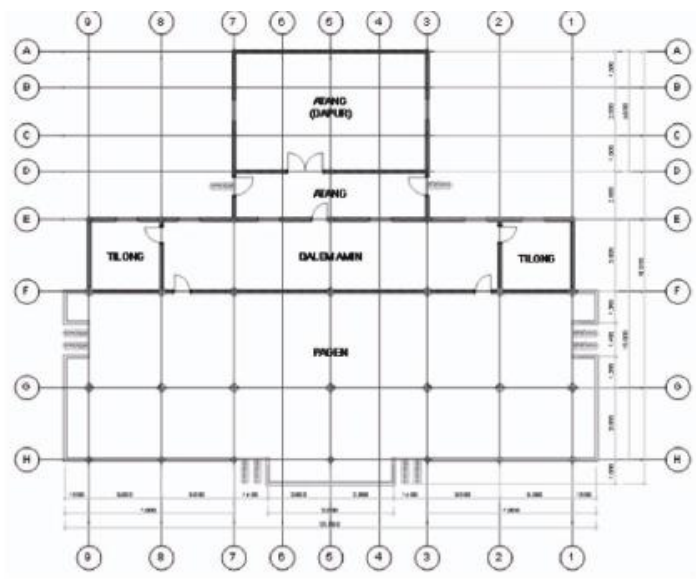

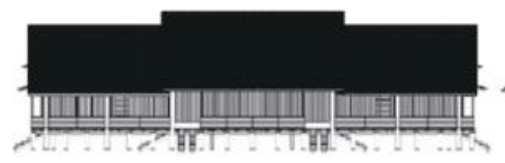

(a)

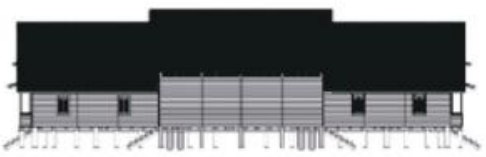

(b)

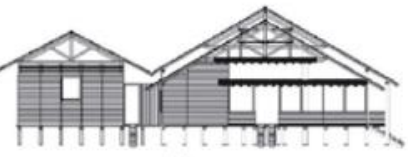

(c)

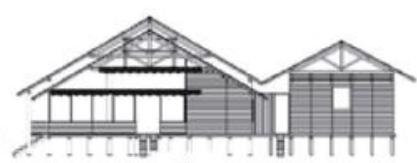

(d) 
Access to the house of Lamin use stairs made of wood with a diameter of $30-40 \mathrm{~cm}$, which were cut in pieces to form the stair. The stair is removable and can be used upside down. The size of Lamin House varied based on the length needed. The floor of Lamin (Asoq) consists of four layers i.e. merurat (first gelagar), matukung (second gelagar), lala (lower part floor), and the upper part is a row of timber wood board (Latenrilawa, 2014).
From the ornamentation aspect, the Lamin Dayak House mostly uses carving with motif of plants and animals with social and symbolical meaning (Ramadhan and Sholihah, 2016). The carving located on various parts of the building such as wall, column, door, window, and tip of the roof.

Figure 7 The layout and architectural look of Lamin Dayak Kenyah House (Source: Lamin Tanjung Isyui, Kutai Barat, 2011)

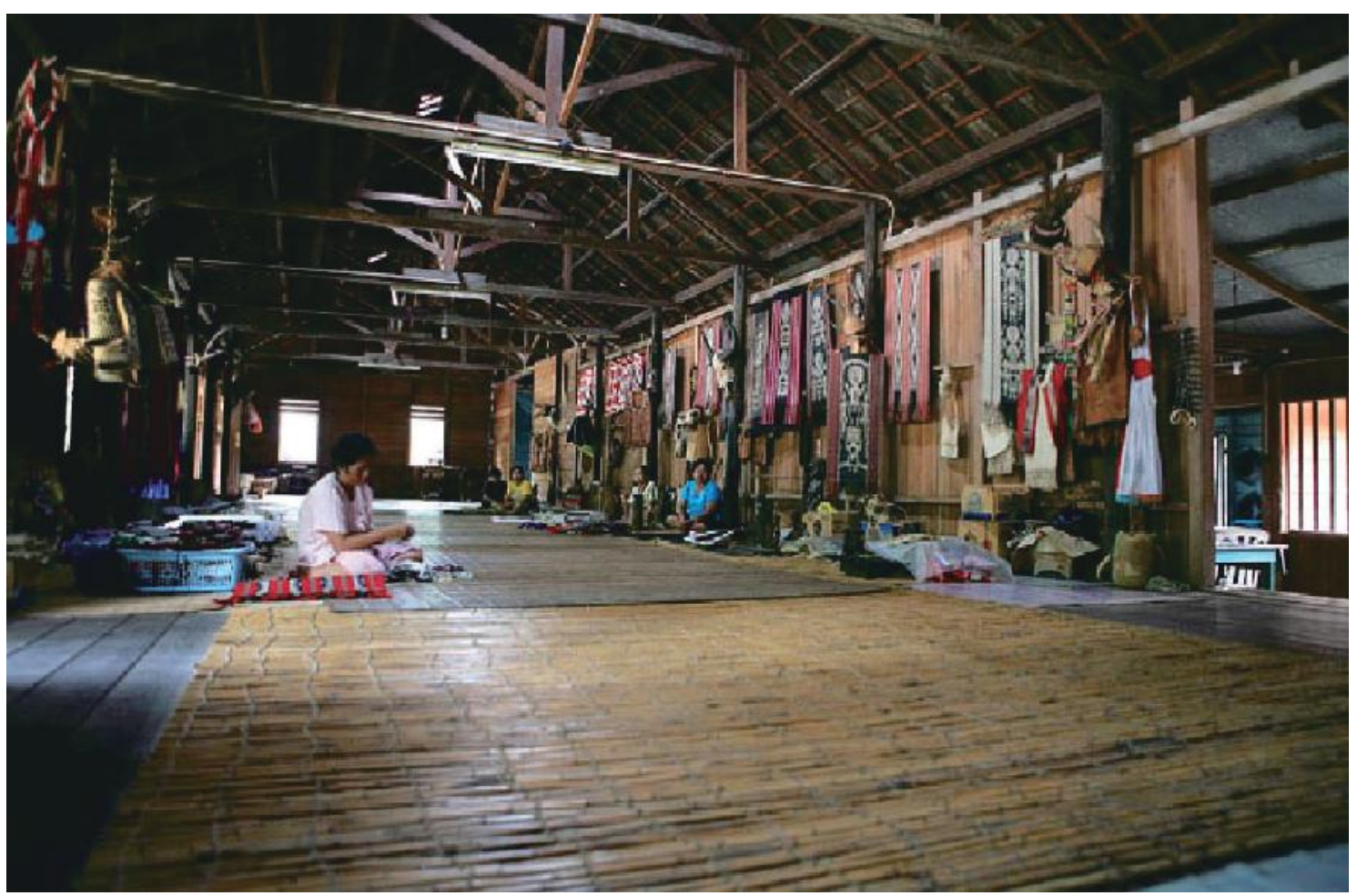

Figure 8. The carving in Lamin Dayak Kenyah House (Source: Ramadhan \& Sholihah, 2016).
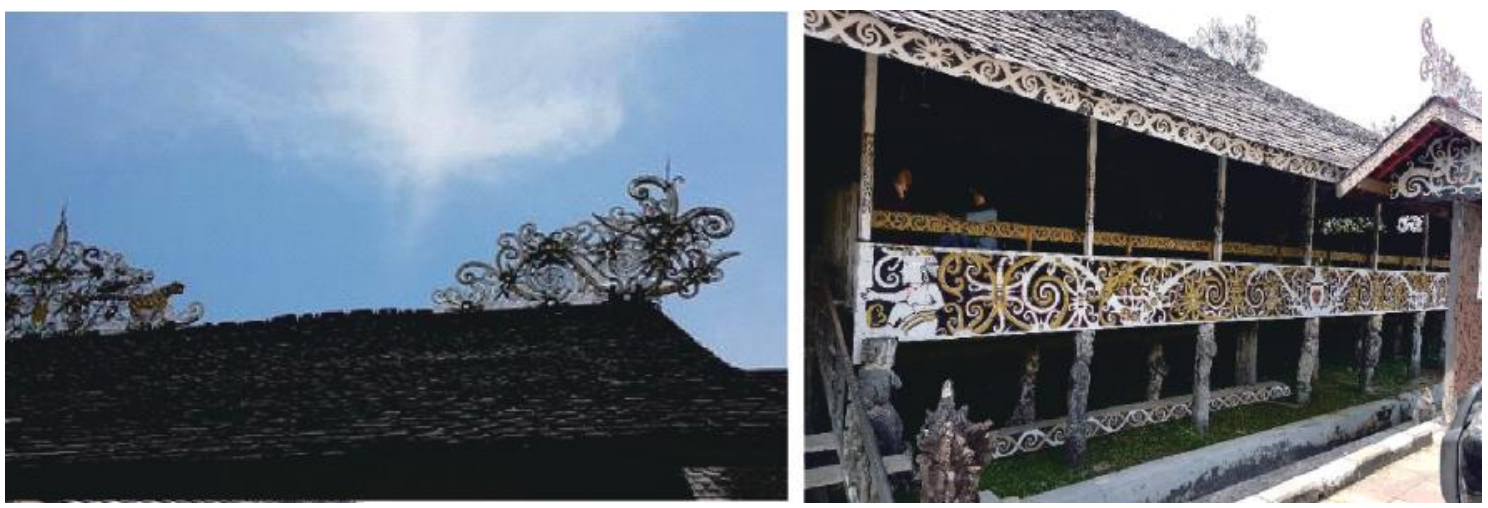


\section{Architecture of Kutai in Tenggarong}

Figure 9. Traditional House of Kutai in Tenggarong (Source: Sholihah, 2016)

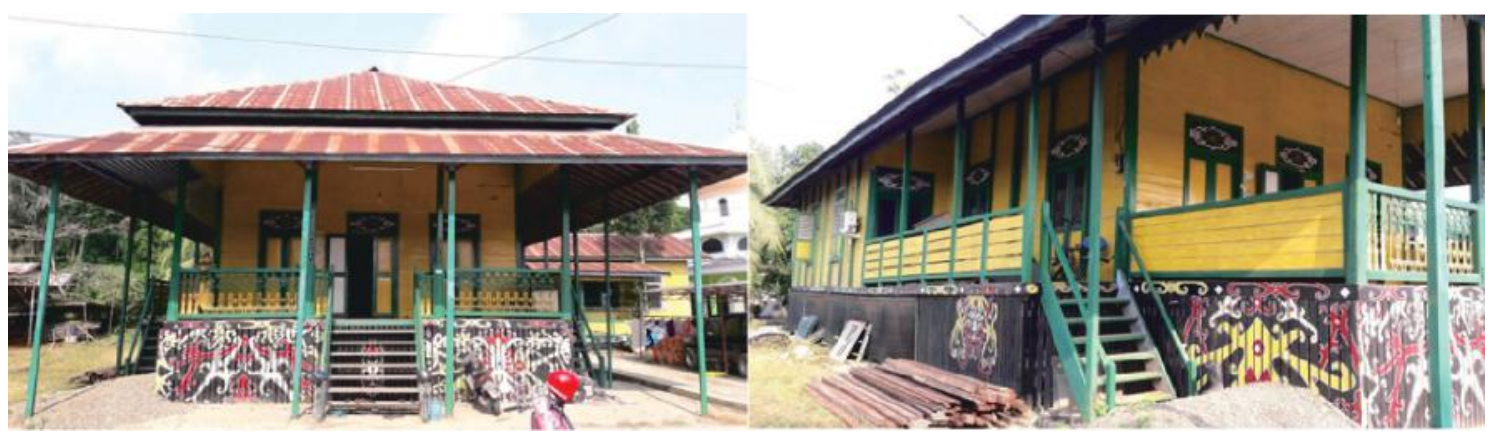

The house in figure 9 is located on Awang Long Senopati Street, Sukarame, Tenggarong, Kutai Kartanegara. In the interview, the interviewee stated that the house was built in 1844 based on the writing on one of the main columns of the house.

The house has been inherited to the fifth generation in the family up to this present. Since the beginning, the house is made for residential need (not cultural house) and it only has minor change on the shape and the construction. From field observation and measured drawing, it can be stated that the structure of the house is stage house type with the height of
1.5 meters with the structure of column frame made of beam wood. In total, the number of columns is 104 with 4 columns in the back part of the house made from one piece uncut wood that has the dimension connection of 12 meters with special treatment. The flat from one of the columns has a hole in the upper part that functions as the place to save jewelry or small accessories, which has symbolical values for the house owner.

Figure 10 Layout and Axonometric of Traditional House of Kutai in Tenggarong (Source: Sholihah, 2016)
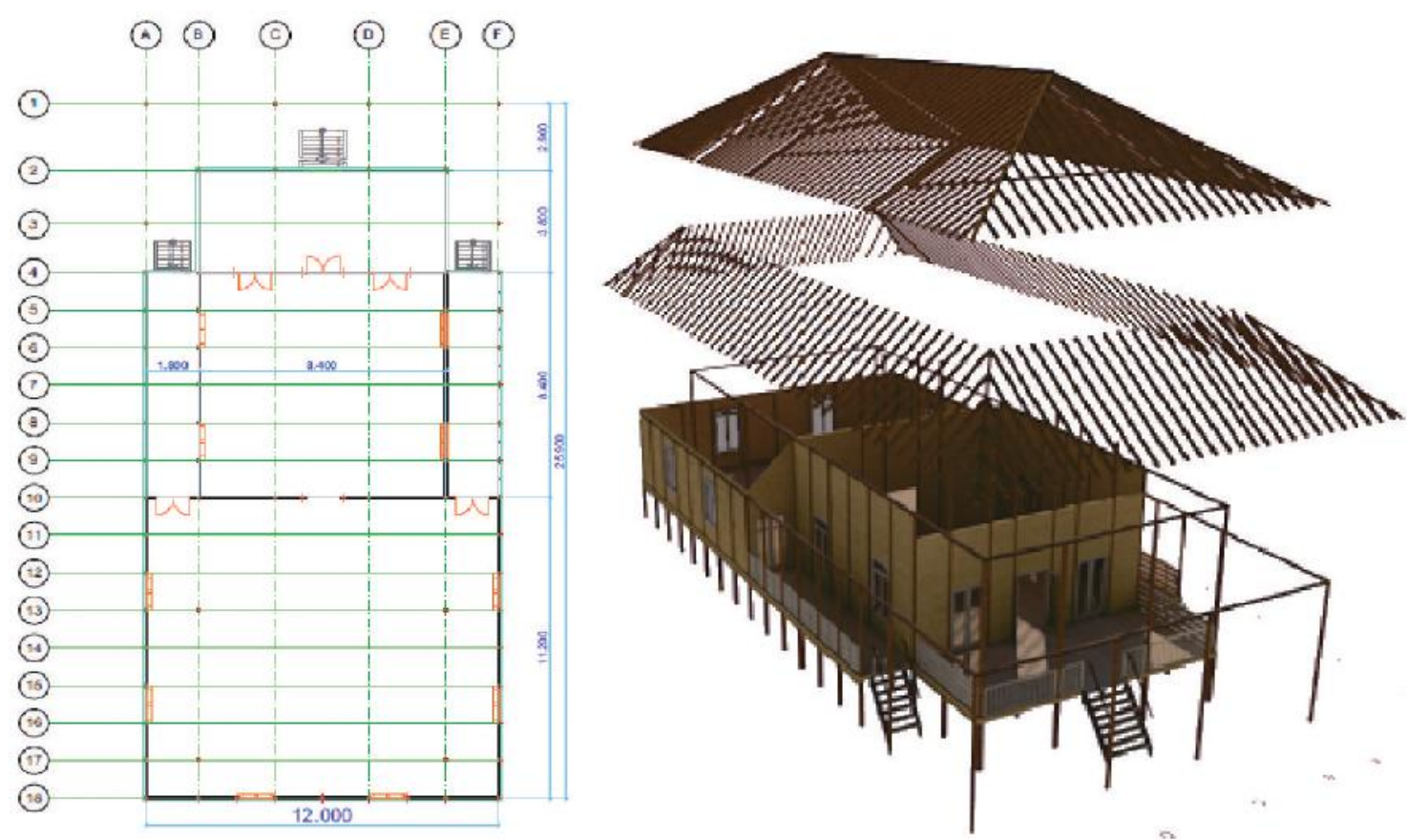
The layout of the building consists of four parts i.e. veranda, middle room, corridor, and back room. The veranda functions as the place to relax and to welcome guests. The middle room functions as the place to enjoy meal with guests and traditional ceremony. Meanwhile, the back room has multifunction as family room, bedroom, and kitchen. The wall is made of pieces of wood with the size of $140 \mathrm{~cm} \times 15 \mathrm{~cm}$ with the thickness of $3 \mathrm{~cm}$ to cover the middle and back room while the veranda and corridor are only bordered with fence wall with the height of less than 1 meter. The roof has two levels and it has space in between for air circulation. The lower part of the roof is supported by the column in the circle of the house while the upper part of the roof is supported by the column in the house circle.

The ornamentation of this building mostly used motif of plants and it has stronger sense of geometric and simple with not so many ornaments. Nevertheless, in the development, the owner of the house added some special carving of Dayak in space underneath the house and on the stairs.
The orientations of the three houses are varied. Melayu Perak House faces to the street, while Lamin Dayak and Kutai Houses make river as the main orientation of the building. The layouts of the houses are almost similar consisting of four main rooms such as guests' rooms (veranda or living room), middle room, and back room (bedroom and kitchen). The three cases have similarities with other Nusantara architectures i.e. the parts form of houses. The roofs of the three are almost similar, which are gabble roofs, but Lamin Dayak and Kutai

Houses have two levels that enable air circulation between the levels of roof. From the ornamental aspect, Lamin Dayak has the most elaborated ornaments using the motif of plants, animals, and humans while the Melayu architecture uses arabesque style with shape of plants and geometry. The architecture of Kutai is the simplest because it only uses simple geometric ornament but it also got other influence from Lamin Dayak architecture.

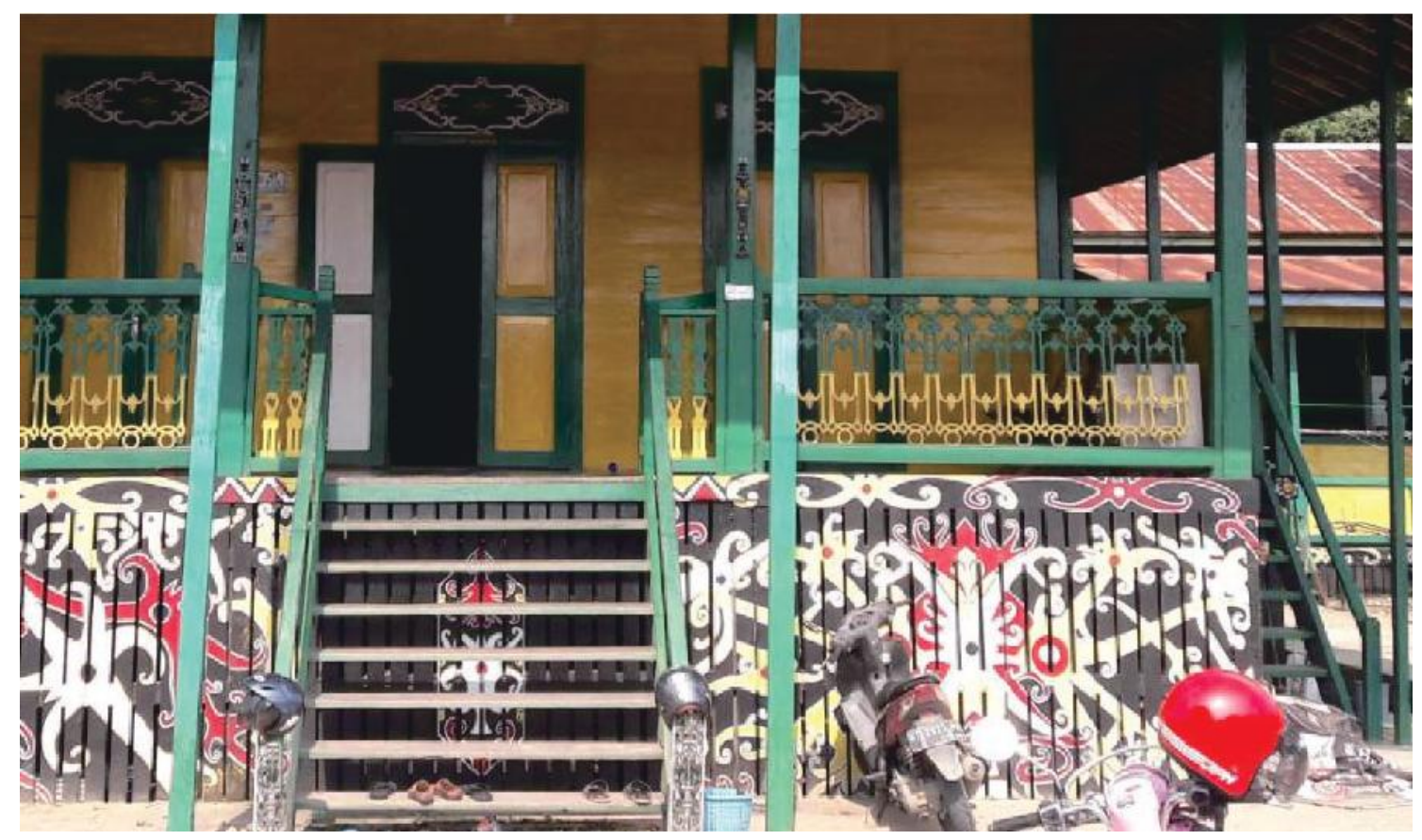


Tabel 1 Analysis on the Comparison between Dayak Kenyah House, Melayu Perak House, and Traditional House of Kutai.

\begin{tabular}{|c|c|c|c|}
\hline & $\begin{array}{l}\text { Melayu Perak House } \\
\text { (a) }\end{array}$ & $\begin{array}{l}\text { Lamin Dayak House } \\
\text { (b) }\end{array}$ & $\begin{array}{l}\text { Kutai House } \\
\text { (c) }\end{array}$ \\
\hline \multirow[t]{3}{*}{$\begin{array}{l}\text { Building } \\
\text { Orienta- } \\
\text { tion and } \\
\text { Lay Out }\end{array}$} & $\begin{array}{l}\text { Square - Facing to } \\
\text { the road - The lay out } \\
\text { con-sists of } 4 \text { parts } \\
\text { (veran-da, middle } \\
\text { room, bed room, and } \\
\text { back room) }\end{array}$ & $\begin{array}{l}\text { Rectangle - lengthwise direction to } \\
\text { the side - facing to the river - layout } \\
\text { consists of four parts (guests com- } \\
\text { mon room (pagen), middle room } \\
\text { (dalem amin), bed room (tilong), and } \\
\text { kitchen (atang)) }\end{array}$ & $\begin{array}{l}\text { Rectangle - lengthwise direc- } \\
\text { tion to the back-- facing to the } \\
\text { river - lay-out consists of four } \\
\text { parts (veranda, middle room, } \\
\text { corridor, and back rooms } \\
\text { (kitchen and bed room) }\end{array}$ \\
\hline & & . & (c) \\
\hline & \multicolumn{3}{|c|}{$\begin{array}{l}\text { a) Kutai Perak Floorplan, Malaysia b) Lamin Floorplan, Dayak Kenyah c) Kutai Kartanegara } \\
\text { Floorplan }\end{array}$} \\
\hline $\begin{array}{l}\text { Main } \\
\text { Access }\end{array}$ & Stairs - Assembled & tairs - stem of a Tree & Stairs - Assembled \\
\hline Structure & Symmetric - Stage & Symmetric - Stage & Symmetric - Stage \\
\hline Walls & $\begin{array}{l}\text { Assembled wooden } \\
\text { board - carved - } \\
\text { cover the whole } \\
\text { building }\end{array}$ & $\begin{array}{l}\text { Assembled wooden board - no } \\
\text { motif -only covers the inner part of } \\
\text { the room }\end{array}$ & $\begin{array}{l}\text { Assembled wooden board - } \\
\text { no motif - co-vers almost the } \\
\text { whole building }\end{array}$ \\
\hline $\begin{array}{l}\text { Building } \\
\text { parts and } \\
\text { roof }\end{array}$ & $\begin{array}{l}\text { The building consists } \\
\text { of three parts (tripar- } \\
\text { tite house). The roof } \\
\text { has one level - the } \\
\text { central part of the } \\
\text { gabble roof widens to } \\
\text { the sides }\end{array}$ & $\begin{array}{l}\text { The building consists of three parts } \\
\text { (tripartite house). The roof has two } \\
\text { levels - the upper part of the gab- } \\
\text { ble roof and lower part of the roof } \\
\text { widens to the sides - the cavity be- } \\
\text { tween roofs becomes the channel } \\
\text { for water circulation }\end{array}$ & $\begin{array}{l}\text { The building consists of three } \\
\text { parts (tripartite house). The } \\
\text { roof has two levels -the up- } \\
\text { per part of the gabble roof and } \\
\text { lower part of the roof widens to } \\
\text { the sides - the cavity between } \\
\text { roofs becomes the channel for } \\
\text { water circulation }\end{array}$ \\
\hline & a) & b) & hing $\frac{R}{B}$ \\
\hline $\begin{array}{l}\text { Orna- } \\
\text { ment }\end{array}$ & $\begin{array}{l}\text { Using the style of Ara- } \\
\text { besque - Geomet- } \\
\text { ric- using plants as } \\
\text { motif - clear picture } \\
\text { of plants }\end{array}$ & $\begin{array}{l}\text { Using special motif of Dayak - half } \\
\text { symmetric, half not - using plants, } \\
\text { humans, and animals as motif - } \\
\text { shape is illustrated like spirits }\end{array}$ & $\begin{array}{l}\text { Motif is almost similar with } \\
\text { Dayak - Geometric - using } \\
\text { plants as motif, but simpler }\end{array}$ \\
\hline Function & $\begin{array}{l}\text { Residence - single- } \\
\text { family dwelling }\end{array}$ & Residence - multi - family dwelling & $\begin{array}{l}\text { Residence - single - family } \\
\text { dwelling }\end{array}$ \\
\hline
\end{tabular}




\section{Conclusion}

These research findings contributed more knowledge about the diversity of architecture from Kutai Kartanegara as part of Nusantara culture, which is similar to other ethnicities (e.g. Dayak and Melayu). However, it still has some indistinctiveness that can be seen as local identity of Kutai architecture. This study is still limited to single case study so that comparison with similar architecture cannot be done. Thus, further research should be conducted to explore the wealth and diversity of architecture from Kutai Kartanegara as one of the historical places in Indonesia.

\section{Reference}

Ariffin, M., \& Talib, A. (2008). Perak Malay (Kutai) architecture: A methodological approach in extensive survey and analysis. In 3rd International Qualitative Research Convention, Universiti Teknologi Malaysia and Qualitative Research Association of Malaysia.

Hidayati, Z., \& Octavia, H.S. (2014). Konservasi Struktur dan Konstruksi Rumah Vernakular Kutai terhadap Lingkungan Rawan Banjir di Tenggarong. Simposium Nasional RAPI XIII-FT UMS, Surakarta.

Hidayati, Z. \& Octavia, H. C. (2013). Studi Adaptasi Rumah Vernakular Kutai terhadap Lingkungan Rawan Banjir di Tenggarong. DIMENSI (Journal of Architecture and Built Environment), 40(2), 89-98.

King VT. (1993). The Peoples of Borneo. Blackwell Publishers: Oxford.

Kristian, Y.D. (2014) Rumah Lamin Dayak Kenyah, http://budaya-indonesia.org
Latenrilawa, R. (2014). Arsitektur Dayak Kenyah, http://ruslanabdullah61.wordpress. com/2014/11/23/arsitektur-dayak-kenyah/

Nas, P.J.M (2004). Ethnic Identity in Urban Architecture: Generations of Architects in Banda Aceh, in Indonesian Houses, edited by Schefold, et al. Singapore University Press, Singapore

Noble, A.G., (2007). Traditional Buildings: A Global Survey of Structural Forms and Cultural Functions, I.B Tauris, London.

Norhasandi, M.A.M., Rashid, M.A., \& Hanafi, Z. (2012). The Architecture of Perak Traditional Malay Roof Houses (PTMRH) In The Year of 1820-1940: A Chronological Analysis of The Arabesque Types on Wall of Rumah Ibu. The 9th Regional Symposium of The Malay Archipelago 2012 (SIMPOSIUM NUSANTARA 9 2012).

Oliver, P. (1997). Encyclopedia of vernacular architecture of the world. Cambridge University Press.

Proshansky, H.M., et al., (1983) Place Identity: Physical World Socialization of the Self, Journal of Environmental Psychology, Vol. 3, 57-83

Ramadhan, T.A \& Sholihah, A.B. (2016) Makna Simbolis dan Makna Sosial Elemen Ukiran Rumah Lamin Dayak Kenyah dan Posisinya pada Bangunan, Laporan Karya Tulis IImiah, tidak dipublikasikan.

Rapoport, A. (1981). Identity and environment: A crosscultural perspective. Housing and identity: Crosscultural perspectives, 6-35. 
Relph, E. (1976). Place and placelessness (Vol. 67). London: Pion.

Rudofsky, B. (1964). Architecture without architects: a short introduction to non pedigreed architecture. UNM Press.

Schefold, R, et al. (2004) Introduction, in Indonesian Houses edited by Schefold, et al. Singapore University Press, Singapore
Yuuwono, A. B. (2015). Peran, Fungsi dan Makna Arsitektur Rumah Lamin dalam Budaya Adat Suku Dayak di Kutai Barat Kalimantan Timur. Teknik Sipil dan Arsitektur, 16(20).

Tjahjono, G \& Miksic, J. (2003). Architecture (Indonesia Heritage), Vol.6, Archipelago Press, Singapore. 